\title{
Rietveld quantitative phase analysis of Yeelimite-containing cements
}

\author{
G. Álvarez-Pinazo a , A. Cuesta ${ }^{\text {a }, ~ M . ~ G a r c i ́ a-M a t e ́ ~ a ~, ~ I . ~ S a n t a c r u z ~ a ~, ~ E . R . ~ L o s i l l a ~}{ }^{\text {a }}$, \\ A.G. De la Torre ${ }^{\text {a }}$, L. León-Reina ${ }^{\text {b }}$, M.A.G. Aranda ${ }^{a, *}$ \\ a Departamento de Química Inorgánica, Cristalografía y Mineralogía, Universidad de Málaga, 29071 Málaga, Spain \\ b Servicios Centrales de Apoyo a la Investigación, Universidad de Málaga, 29071 Málaga, Spain
}

\section{A R T I C L E I N F O}

\section{Article history:}

Received 6 December 2011

Accepted 26 March 2012

\section{Keywords:}

$4 \mathrm{CaO} \cdot 3 \mathrm{Al} 2 \mathrm{O} 3 \cdot \mathrm{CaSO} 4(\mathrm{D})$

Calcium sulfoaluminate (D)

X-ray diffraction analysis $(\mathrm{B})$

Rietveld method (B)

Amorphous material (B)

\begin{abstract}
A B S T R A C T
Yeelimite-containing cements are attracting attention for their tailored properties. Calcium sulfoaluminate, CSA, cements have high contents of Yeelimite and they are used for special applications. Belite calcium sulfoaluminate, BCSA or sulfobelite, cements have high contents of belite and intermediate contents of Yeelimite, and they may become an alternative to OPC. Here, we report Rietveld quantitative phase analyses for three commercially available CSA clinkers, one CSA cement, and two laboratory-prepared iron-rich BCSA clinkers. The crystalline phases are reported and quantified. Selective dissolutions are employed for BCSA clinkers to firmly establish their phases. Finally, the overall unaccounted contents (amorphous plus crystalline not quantified) have been determined by two approaches: i) external standard procedure (G-method) with reflection data; ii) internal standard procedure (spiking method with $\mathrm{ZnO}$ ) with transmission data. The overall unaccounted contents for CSA clinkers were $\sim 10$ wt.\%. Conversely, the unaccounted contents for BCSA clinkers were higher, $25 \mathrm{wt} . \%$.
\end{abstract}

(c) 2012 Elsevier Ltd. All rights reserved.

\section{Introduction}

Calcium sulfoaluminate (CSA) cements have been applied worldwide from the 60s as expansive binders mixed with Portland cements [1]. These cements are characterized by containing high amounts of Yeelimite, also called Klein's salt or tetracalcium trialuminate sulfate $\left(\mathrm{C}_{4} \mathrm{~A}_{3} \mathrm{~S}\right)$. Hereafter, cement nomenclature will be used, i.e. $\mathrm{C}=\mathrm{CaO}, \mathrm{S}=\mathrm{SiO}_{2}, \mathrm{~A}=\mathrm{Al}_{2} \mathrm{O}_{3}, \mathrm{~F}=\mathrm{Fe}_{2} \mathrm{O}_{3}, \mathrm{M}=\mathrm{MgO}$, $\mathrm{S}=\mathrm{SO}_{3}, \mathrm{C}=\mathrm{CO}_{2}, \mathrm{H}=\mathrm{H}_{2} \mathrm{O}, \mathrm{K}=\mathrm{K}_{2} \mathrm{O}$ and $\mathrm{N}=\mathrm{Na}_{2} \mathrm{O}$. Therefore, $\mathrm{C}_{4} \mathrm{~A}_{3} \mathrm{~S}$ corresponds to $\mathrm{Ca}_{4} \mathrm{Al}_{6} \mathrm{O}_{12}\left(\mathrm{SO}_{4}\right)$. During the 70 s, CSA cements were introduced into the Chinese market as high performance and dimensionally stable cementitious matrices developed by the China Building Materials Academy [2]. In Europe, the use of CSA cements is strongly limited by the lack of standards concerning special cements derived from non-Portland clinkers. Nevertheless, their manufacture has recently been started by several companies. The main use of these CSA cements, or blends with Portland cements, is for quick repairs and pre-cast products or floor concrete applications.

Moreover, Yeelimite-containing cements have become highly popular over the last few years for research. The driving force for these investigations is the much lower $\mathrm{CO}_{2}$ emissions in their manufacture when compared to those of Portland cement production due to the following main reasons [3,4]: i) Yeelimite releases during its synthesis only a third part of the $\mathrm{CO}_{2}$ released by the production of

\footnotetext{
* Corresponding author. Tel.: + 34 952131874; fax: + 34952132000 E-mail address: g_aranda@uma.es (M.A.G. Aranda).
}

alite, ii) firing temperature is about $200{ }^{\circ} \mathrm{C}$ lower than that of OPC clinker, iii) various industrial by-products can be used in the kiln feed, and iv) Yeelimite-containing clinkers are easier to grind than OPC clinkers. The improvement of cement performances and the reduction of the environmental impact related to its manufacture are most likely the main areas of innovation for the cement industry [5]. It must be highlighted that CSA cements may have important special applications such radioactive element encapsulation in high-density cement pastes [6]. Other interesting properties of Yeelimite-containing cements are high early strengths, short setting times, low solution alkalinity as well as high impermeability and chemical resistance against several aggressive media [7].

However, while the composition of Portland cement is defined by long-standing codes and standards, there is no corresponding compositional framework for Yeelimite-containing cements. These clinkers may show very variable phase assemblage. The raw mix composition can be based on conventional raw materials (limestone, clay, bauxite and iron ores); in addition, industrial by-products and wastes can also be added $[8,9]$. Yeelimite-containing cements could be classified according to their $\mathrm{C}_{4} \mathrm{~A}_{3} \mathrm{~S}$ contents as:

I) Calcium sulfo-aluminate (CSA) cements which would refer to those with high $C_{4} A_{3} S$ contents. They may be prepared from CSA clinkers containing $\mathrm{C}_{4} \mathrm{~A}_{3} \mathrm{~S}$ as the main phase ranging between 50 and $90 \mathrm{wt} . \%$ [10]. The calcium sulfate addition is very important as it may profoundly affect the properties of the resulting binder [11-13]. The calcium sulfate source and content have to be customized for a given application. These 
cements can be used alone or in combination with other cements to provide an improved early resistance, low shrinkage, high impermeability, and a strong resistance to sulfate attack.

II) Belite calcium sulfo-aluminate (BCSA) cements which would refer to those with $C_{2} S$ (belite) as the main phase and intermediate $\mathrm{C}_{4} \mathrm{~A}_{3} \mathrm{~S}$ contents. These cements, also known as sulfobelite, are prepared from clinkers containing more than $40-50$ wt.\% of $\mathrm{C}_{2} \mathrm{~S}$ and $20-30 \% \mathrm{C}_{4} \mathrm{~A}_{3} \mathrm{~S}$. The most common formulation of BCSA clinkers consists of $\beta-C_{2} S, C_{4} A_{3} S$ and $C_{4} A F$ [6,14-18]. These are iron-rich BCSA cements, also termed as BCSAF, and they are produced at $\sim 1250{ }^{\circ} \mathrm{C}$ and show a rapid hardening, excellent durability, self-stressing and volume stability, depending on the amount of gypsum added [19]. Recently, a new class of BCSAF cement has been proposed by Lafarge $[15,20,21]$ in which stabilization of high temperature belite polymorphs ( $\alpha$-forms) has been promoted (for instance with borax) to enhance early age hydration of these cements. Alternatively, in order to further enhance mechanical strengths at very early ages, $<1$ day, $\mathrm{C}_{4} \mathrm{AF}$ phase may be substituted by $\mathrm{C}_{12} \mathrm{~A}_{7}$; however, the clinkering temperature should be increased $\sim 100{ }^{\circ} \mathrm{C}$ and the durability with respect to sulfate attack is limited [22,23]. This formulation corresponds to aluminum-rich BCSA clinkers (or BCSAA) with $\mathrm{C}_{2} \mathrm{~S}, \mathrm{C}_{4} \mathrm{~A}_{3} \mathrm{~S}$, $\mathrm{C}_{12} \mathrm{~A}_{7}$ and $C A$ as main phases [24]. In this type of clinkers, aluminate phases and $\mathrm{C}_{4} \mathrm{~A}_{3} \mathrm{~S}$ are responsible for the early strength development, while $\mathrm{C}_{2} \mathrm{~S}$ provides hardening at much later ages. An in-situ study of the clinkering of both BCSAF and BCSAA samples has been very recently reported using highenergy synchrotron X-ray powder diffraction [25].

III) Alite calcium sulfo-aluminate (ACSA) cements which would correspond to those characterized by the simultaneous presence of $C_{3} S$ and $C_{4} A_{3} S$ phases. In this special case, Yeelimite phase content may be even higher than that of alite [26]. Other phases may appear in the clinkers including $C_{2} S$ and $C_{3} A$. However, this type of clinker is quite difficult to prepare because the optimum temperatures for the synthesis of the two phases differ considerably. Nevertheless the addition of a small amount of $\mathrm{CaF}_{2}$ (and/or $\mathrm{CuO}, \mathrm{TiO}_{2}$ ) to the raw mixes allows the coexistence of both phases at temperatures between 1230 and $1300{ }^{\circ} \mathrm{C}$.

CSA and BCSA clinkers are complex materials due to the presence of many crystalline phases, some of them also displaying polymorphism. $\mathrm{X}$-ray powder diffraction (XRPD) is the most appropriate technique to identify, characterize and quantify the crystalline phases within these samples. The application of Rietveld methodology [27] to XRPD data in order to obtain quantitative phase analyses (RQPA) was reported long time ago [28]. To derive the phase contents from the Rietveld optimized scale factors, this methodology normalizes the results to $100 \%$ of crystalline phases (i.e. the presence of amorphous content is not taken into account). Therefore, if the mixture has an appreciable amount of amorphous phase, this method is considered as semiquantitative. To overcome this problem, two approaches have been developed, the internal and the external standard methods (to be briefly described just below). The presence of a glassy or amorphous component in Portland cements and clinkers has been debated by several authors [29-31].

I) Internal standard method or "spiking method", which consists on the addition of a known amount of a crystalline standard, $\mathrm{W}_{\mathrm{st}}$. This standard must be free of amorphous content or at least it should contain a known non-diffracting content. This (artificial) mixture must be well homogenized since the particles should be randomly arranged. The addition of the standard will dilute the crystalline phases within the samples, hence this may be a problem for lowcontent phases. A procedure for Rietveld quantitative amorphous content analysis was outlined elsewhere [32] and the effects of systematic errors in the powder patterns were studied. A very recent report uses this methodology in depth [33]. This method permits the determination of an overall unaccounted content which is composed by amorphous phase(s), misfitting problems of the analyzed crystalline phases, and because some crystalline phases may not be included in the control file due to several reasons (its crystal structure is not known, the phase was not identified, etc.). This overall content is hereinafter named ACn which stands for Amorphous and Crystalline not-quantified, to highlight that not only an amorphous fraction but also any notcomputed crystalline phase and any misfit problem (for instance the lack of an adequate structural description for a given phase) may contribute to this number.

II) External standard method (G-factor approach), which consists in recording two patterns (one for the sample and another for the standard). It is possible to use an external standard method to avoid the complications that may arise from mixing an internal standard with the sample. This approach requires the recording of two patterns in identical diffractometer configuration/conditions for Bragg-Brentano $\theta / 2 \theta$ reflection geometry. The method was proposed by O'Connor and Raven [34] and very recently applied to anhydrous cements [35] and to pastes [36]. This methodology is also known as G-method since the standard allows calculating the $\mathrm{G}$-factor of the diffractometer in the operating conditions. This calculated G-factor represents a calibration factor for the whole experimental setup and comprises the used diffractometer, radiation, optics, and all data acquisition conditions (f.i. detector configuration, integration time, etc.). It is experimentally more demanding but it may have the brightest future as it does not interfere with the hydration reactions.

In this work, we report Rietveld quantitative phase analysis for several Yeelimite-containing clinkers and cements. Both CSA and BCSAF clinkers have been studied to illustrate the suitability of Rietveld methodology. Furthermore, the ACn contents have been determined using both strategies, internal and external standard procedures. The obtained results are discussed.

\section{Experimental section}

\subsection{Material description}

In this work, six different types of Yeelimite-containing samples have been investigated. Three of them are commercially available CSA clinkers. A CSA cement prepared in an industrial trial, but not commercially available, has been also studied. Finally, two BCSAF clinkers prepared in our laboratory have been also analyzed.

\subsubsection{Commercial CSA clinkers}

The following commercial clinkers with high $\mathrm{C}_{4} \mathrm{~A}_{3} \mathrm{~S}$ contents (ranging between 55 and $70 \mathrm{wt} . \%$ ) have been studied:

- ALIPRE® (2009), a CSA clinker industrially produced by Italcementi Group.

- BELITH_CS10, a CSA clinker industrially produced in China and marketed in Europe by Belith (Belgium).

- S.A.cement, a CSA clinker industrially produced by Buzzi Unicem.

\subsubsection{Non-commercial CSA cement}

A CSA cement, with $\sim 40 \% \mathrm{C}_{4} \mathrm{~A}_{3} \mathrm{~S}$, produced in an industrial trial which is not commercially available has also been studied. This cement is named CSA_trial in this study.

\subsubsection{Laboratory-prepared BCSAF clinkers}

Approximately two kilograms of two BCSAF clinkers have been prepared in our laboratory in several steps. The raw materials were 
weighed to have an expected phase composition of $50 \mathrm{wt} . \% \mathrm{C}_{2} \mathrm{~S}$, $30 \mathrm{wt} . \%$ of $\mathrm{C}_{4} \mathrm{~A}_{3} \mathrm{~S}$ and $20 \mathrm{wt} . \%$ of $\mathrm{C}_{4} \mathrm{AF}$. Table 1 shows the amounts of raw materials used for the preparations. The difference in both samples is the addition of borax in one of them, $2 \mathrm{wt} . \%$ expressed as $\mathrm{B}_{2} \mathrm{O}_{3}$ in the resulting clinker. Hereafter, these clinkers are named BCSAF_B0 and BCSAF_B2, for boron-free and boron-containing clinker, respectively. The raw materials mixture (approximately $3 \mathrm{~kg}$ ) was pre-homogenized for $15 \mathrm{~min}$ in a micro-Deval machine (A0655, Proeti S.A., Spain) at $100 \mathrm{rpm}$ with steel balls ( 9 balls of $30 \mathrm{~mm}, 21$ balls of $18 \mathrm{~mm}$ and a number of balls of $10 \mathrm{~mm}$ up to a total ball weight of $2500 \mathrm{~g}$ ). The mixture was pressed into pellets of about $40 \mathrm{~g}$ ( $55 \mathrm{~mm}$ of diameter and approximately $5 \mathrm{~mm}$ of height). Six pellets, one on top of each other, were placed in a large $\mathrm{Pt} / \mathrm{Rh}$ crucible of $325 \mathrm{ml}$ of volume. The pellets were heated at $900{ }^{\circ} \mathrm{C}$ and held for $30 \mathrm{~min}$ (heating rate of $5^{\circ} \mathrm{C} / \mathrm{min}$ ). Then, they were further heated at $1350{ }^{\circ} \mathrm{C}$ and held for another $30 \mathrm{~min}$ (heating rate of $5{ }^{\circ} \mathrm{C} / \mathrm{min}$ ). Finally, the samples were quenched with air flow. The clinkered pellets were grinded in the micro-Deval mill at $100 \mathrm{rpm}$ for $1 \mathrm{~h}$. Under these milling conditions, all clinker material passed through a $250 \mu \mathrm{m}$ sieve.

\subsubsection{Selective dissolution of laboratory-prepared BCSAF clinkers}

Selective dissolutions have been performed to study the laboratoryprepared BCSAF clinkers [37]. Initially, these clinkers were ground to a Blaine fineness of $\sim 400 \mathrm{~m}^{2} / \mathrm{kg}$.

2.1.4.1. Selective dissolution to remove the aluminate phases (silicate residue). A solution composed of $60 \mathrm{ml}$ demineralized water, $8 \mathrm{~g}$ of $\mathrm{KOH}$ and $8 \mathrm{~g}$ of sucrose was heated to $95^{\circ} \mathrm{C}$ with magnetic stirring in a $250 \mathrm{ml}$ beaker. After around $30 \mathrm{~min}$, it becomes brown-yellow. Then, $4 \mathrm{~g}$ of clinker powder was added and kept under stirring for $15 \mathrm{~min}$. After this treatment, the resulting suspension was filtered with a Whatman system (Whatman filter with diameter $70 \mathrm{~mm}$ ). Once this initial filtration step was finished, the minimum amount of water was added to eliminate the sucrose and finally the residue was rinsed twice with isopropyl alcohol to remove water. After filtration, the residue was mashed with a spatula to break up agglomerated particles, dried and analyzed by XRPD.

2.1.4.2. Selective dissolution to remove the silicate phases (aluminate residue). A mixture of $4 \mathrm{~g}$ of clinker powder, $52 \mathrm{ml}$ methanol and $24 \mathrm{~g}$ salicylic acid was prepared. This mixture was stirred in a $250 \mathrm{ml}$ beaker with a glass cover for $50 \mathrm{~min}$. After that treatment, the mixture was filtered with a Whatman system (Whatman filter with diameter $70 \mathrm{~mm}$ ) and rinsed with ethanol. The residue was dried in an oven at $60{ }^{\circ} \mathrm{C}$ for $30 \mathrm{~min}$, ground and analyzed by XRPD.

\subsection{Analytical techniques}

\subsubsection{Elemental analysis by X-ray fluorescence}

Table 2 gives the elemental analysis for the 6 studied samples prepared as fused beads. The X-ray fluorescence (XRF) data were taken in a Magic X spectrometer (PANalytical, Almelo, The Netherlands) using the calibration curve of silica-alumina materials. The elemental analyses of the raw materials used for the BCSAF clinker preparations are available upon request, but they are not reported here since the analyses of the clinkers are provided.

Table 1

Raw materials employed for the preparation of BCSAF clinkers (expressed in grams).

\begin{tabular}{lllllll}
\hline & Limestone & Kaolin & Bauxite & Gypsum & Marl & Borax \\
\hline BCSAF_B0 & 1796.30 & 281.03 & 519.53 & 227.51 & 209.78 & - \\
BCSAF_B2 & 1744.21 & 272.88 & 504.47 & 220.91 & 203.70 & 120.26 \\
\hline
\end{tabular}

\subsubsection{Inductively coupled plasma mass spectroscopy (ICP-MS)}

The amounts of $\mathrm{Na}_{2} \mathrm{O}$ and $\mathrm{B}_{2} \mathrm{O}_{3}$ in the laboratory-prepared BCSAF clinkers were determined by ICP-MS on Perkin Elmer spectrophotometer (NexION 300D). Previously, the samples were digested in an Anton Paar device (Multiwave 3000 ) by using $\mathrm{HNO}_{3}, \mathrm{HCl}$ and $\mathrm{HF}$.

\subsubsection{Laboratory X-ray powder diffraction}

All six samples were studied by laboratory X-ray powder diffraction (LXRPD) to identify, characterize and quantify the crystalline phases. In order to study the ACn contents, both internal and external standard approaches were employed.

On the one hand, the patterns studied by the external standard method were recorded in Bragg-Brentano reflection geometry $(\theta / 2 \theta)$ on an X'Pert MPD PRO diffractometer (PANalytical B.V.) using strictly monochromatic $\mathrm{CuK} \alpha_{1}$ radiation $(\lambda=1.54059 \AA$ ) [Ge (111) primary monochromator]. In addition to the patterns for the samples to be studied, this approach requires the recording of additional patterns collected in identical diffractometer configuration/conditions for the standard, in this case $\alpha-\mathrm{Al}_{2} \mathrm{O}_{3}$ (SRM-676a). The X-ray tube worked at $45 \mathrm{kV}$ and $40 \mathrm{~mA}$. The optics configuration was a fixed divergence slit $\left(1 / 2^{\circ}\right)$, a fixed incident antiscatter slit $\left(1^{\circ}\right)$, a fixed diffracted antiscatter slit $\left(1 / 2^{\circ}\right)$ and X'Celerator RTMS (Real Time Multiple Strip) detector, working in scanning mode with maximum active length. Data were collected from $5^{\circ}$ to $70^{\circ}(2 \theta)$ for $\sim 2 \mathrm{~h}$. The samples were rotated during data collection at $16 \mathrm{rpm}$ in order to enhance particle statistics. NIST standard reference material SRM-676a, corundum $\left(\alpha-\mathrm{Al}_{2} \mathrm{O}_{3}\right)$ powder, has been certified to have a crystalline phase purity of $99.02 \% \pm 1.11 \%$ (95\% confidence interval) by RQPA against a suitable primary standard, powder silicon carefully prepared from a single crystal [33].

On the other hand, the patterns studied by the internal standard method were recorded in flat-sample transmission geometry on an EMPYREAN diffractometer (PANalytical B.V.) equipped with a $\theta / \theta$ goniometer, $\mathrm{CuK \alpha} \alpha_{1,2}$ radiation $(\lambda=1.542 \AA$ ) and a focusing mirror. This PreFIX optical component is capable of converting the divergent beam into a convergent radiation focused on the goniometer circle. The EMPYREAN diffractometer was equipped with fixed incident and diffracted beam anti-scatter slits of $14^{\circ}$ and $5 \mathrm{~mm}$, respectively. The detector was PIXCEL 3D RTMS, which comprises more than 65,000 pixels, each $55 \times 55 \mu \mathrm{m}$ in size; each having its own circuitry. As internal standard, ZnO (99.99\%, Sigma-Aldrich, St. Louis, MO, USA), was added to the samples to a total content of $25 \mathrm{wt} . \%$. The mixtures were homogenized for $20 \mathrm{~min}$ in an agate mortar. The powder samples (mixed with $\mathrm{ZnO}$ ) were placed in the holders between two Kapton films. The cylindrical sample diameter and thickness were $\sim 10.0 \mathrm{~mm}$ and $\sim 0.3 \mathrm{~mm}$, respectively. The overall measurement time was $\sim 3 \mathrm{~h}$ per pattern to have very good statistic over the $2 \theta$ range of $5-70^{\circ}$ with $0.0131^{\circ}$ step size $(2 \theta)$.

\subsubsection{XRPD data analysis}

Powder patterns of the samples were analyzed by the Rietveld method as implemented in the GSAS software package [38] by using a pseudo-Voigt peak shape function [39] with the asymmetry correction included [40] to obtain Rietveld Quantitative Phase Analysis (RQPA). The refined overall parameters were: phase scale factors, background coefficients, unit cell parameters, zero-shift error, peak shape parameters and preferred orientation coefficient, if needed. March-Dollase ellipsoidal preferred orientation correction algorithm was employed [41]. In addition to these parameters, and only for the Rietveld refinements of transmission powder data, a flat-sample absorption coefficient was also optimized as implemented in GSAS. Table 3 reports the crystal structures used in this study to simulate the crystalline phase powder patterns [Refs. 42-59]. The powder diffraction file (PDF) codes for all identified phases in the studied cements are also given in Table 3. 
Table 2

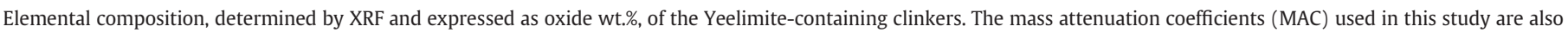
given in italics.

\begin{tabular}{|c|c|c|c|c|c|c|c|}
\hline & ALIPRE® & BELITH_CS10 & S.A.cement & CSA_trial & BCSAF_B0 & BCSAF_B2 & $\operatorname{MAC}\left(\mathrm{cm}^{2} / \mathrm{g}\right)$ \\
\hline $\mathrm{CaO}$ & 41.59 & 41.86 & 44.10 & 45.59 & 51.75 & 50.99 & 120.47 \\
\hline $\mathrm{Al}_{2} \mathrm{O}_{3}$ & 33.64 & 33.85 & 27.30 & 20.93 & 18.78 & 17.03 & 30.91 \\
\hline $\mathrm{SiO}_{2}$ & 6.52 & 8.21 & 9.00 & 10.13 & 16.70 & 16.53 & 34.84 \\
\hline $\mathrm{SO}_{3}$ & 13.97 & 8.81 & 12.20 & 16.66 & 3.68 & 3.70 & 42.48 \\
\hline $\mathrm{Fe}_{2} \mathrm{O}_{3}$ & 0.89 & 2.37 & 2.60 & 3.63 & 6.72 & 6.28 & 220.77 \\
\hline $\mathrm{B}_{2} \mathrm{O}_{3}{ }^{\mathrm{a}}$ & - & - & - & - & 0.13 & 2.37 & 8.26 \\
\hline $\mathrm{Na}_{2} \mathrm{O}^{\mathrm{a}}$ & 0.09 & $<0.08$ & 1.40 & 0.18 & 0.10 & 1.00 & 24.28 \\
\hline $\mathrm{K}_{2} \mathrm{O}$ & 0.39 & 0.25 & 0.30 & 0.31 & 0.34 & 0.33 & 116.82 \\
\hline $\mathrm{MgO}$ & 0.68 & 2.73 & 1.50 & 1.26 & 0.99 & 0.97 & 27.88 \\
\hline $\mathrm{TiO}_{2}$ & 1.48 & 1.50 & 1.30 & 1.00 & 0.65 & 0.62 & 121.97 \\
\hline $\mathrm{SrO}$ & 0.50 & 0.15 & 0.20 & 0.17 & 0.028 & 0.03 & 100.36 \\
\hline $\mathrm{Cr}_{2} \mathrm{O}_{3}$ & - & 0.017 & - & 0.02 & 0.028 & 0.023 & 176.40 \\
\hline $\mathrm{MnO}$ & - & 0.011 & - & 0.02 & 0.036 & 0.034 & 217.87 \\
\hline $\mathrm{ZrO}_{2}$ & 0.10 & 0.070 & - & 0.05 & 0.021 & 0.019 & 104.15 \\
\hline $\mathrm{P}_{2} \mathrm{O}_{5}$ & 0.16 & 0.13 & 0.10 & 0.04 & 0.055 & 0.059 & 38.59 \\
\hline $\operatorname{MAC}\left(\mathrm{cm}^{2} / \mathrm{g}\right)$ & 73.81 & 75.96 & 78.56 & 82.31 & 92.00 & 89.28 & - \\
\hline
\end{tabular}

a $\mathrm{B}_{2} \mathrm{O}_{3}$ and $\mathrm{Na}_{2} \mathrm{O}$ contents were measured by ICP-MS.

The output of a RQPA study for a sample with m-crystalline phases is a set of $\mathrm{m}$-crystalline phase scale factors, $\sum_{\mathrm{m}} \mathrm{S}_{\alpha}$. A phase scale factor, $S_{\alpha}$, is related to the phase weight content, $W_{\alpha}$, by Eq. (1) [28].

$\mathrm{S}_{\alpha}=\mathrm{K}_{\mathrm{e}} \frac{\mathrm{W}_{\alpha}}{(\mathrm{ZMV})_{\alpha} \mu_{\mathrm{s}}}$

Where $K_{e}$ is a constant which depends on the diffractometer operation conditions, $\mu_{\mathrm{s}}$ is the sample mass absorption coefficient, $\mathrm{Z}$ is the number of chemical units/formulas within the unit cell of $\alpha$-phase, $\mathrm{M}$ is the molecular mass of the chemical formula for $\alpha$-phase, and $\mathrm{V}$ the unit cell volume for $\alpha$-phase. Once the crystal structure is known, the 'ZMV' term is known. The parameter of interest, $\mathrm{W}_{\alpha}$, depends not only on the phase scale factor, $S_{\alpha}$, but also on $K_{e}$ and $\mu_{s}$. Unfortunately, these two variables are not known and they can not be derived from the single powder diffraction pattern of the sample under study.

Currently, there are three main ways to derive the phase content, $\mathrm{W}_{\alpha}$, from the Rietveld refined scale factor, $\mathrm{S}_{\alpha}$. These three methods are based on different mathematical approaches and they have different experimental complexities. They are very briefly discussed below.

2.2.4.1. Normalization to full crystalline content method. The simplest approach is the approximation that the sample is only composed of crystalline phases with known structures. These crystal structures are used to compute the powder pattern with any Rietveld program code, in this case GSAS. Under this approximation, $\mathrm{W}_{\alpha}$ is given by Eq. (2) [28]:

$\mathrm{W}_{\alpha}=\frac{\mathrm{S}_{\alpha}(\mathrm{ZMV})_{\alpha}}{\sum_{\mathrm{i}=1}^{\mathrm{m}} \mathrm{S}_{\mathrm{i}}(\mathrm{ZMV})_{\mathrm{i}}}$
The use of Eq. (2) in RQPA eliminates the need to measure the instrument calibration constant, $\mathrm{K}_{\mathrm{e}}$, and the sample mass absorption coefficient, $\mu_{\mathrm{s}}$. However, the method normalizes the sum of the analyzed weight fractions to 1.0. Thus, if the sample contains amorphous phases, and/or some amounts of unaccounted crystalline phases, the analyzed weight fractions will be overestimated. This approach is by far the most widely used method in RQPA. However, it must be highlighted that the resulting weight fractions are only accurate if the $\mathrm{ACn}$ amount is very small (negligible).

2.2.4.2. External standard method (G-factor approach). One possibility to quantify the amount of the ACn content is to use the G-factor approach by employing a suitable external standard. In this approach, the diffractometer constant, $\mathrm{K}_{\mathrm{e}}$, is calculated according to Eq. (3) (in this case the standard was NIST $\mathrm{Al}_{2} \mathrm{O}_{3}$ ) [34]:

$\mathrm{G}=\mathrm{K}_{\mathrm{e}}=\mathrm{S}_{\mathrm{st}} \frac{\rho_{\mathrm{st}} \mathrm{V}_{\mathrm{st}}^{2} \mu_{\mathrm{st}}}{\mathrm{W}_{\mathrm{st}}}$

where $S_{s t}$ is the Rietveld scale factor of the (external) standard, $\rho_{\text {st }}$ is the density of the standard, $V_{s t}$ is the unit cell volume of the standard, $\mathrm{W}_{\mathrm{st}}$ is the weight fraction the standard (in our case $100 \mathrm{wt} . \%$ ), all values derived from the Rietveld refinement of the external standard pattern collected in identical conditions than those of the cements. $\mu_{\mathrm{st}}$ is the mass attenuation coefficient of the standard. This G-factor (the average of three independent measurements) was used to determine the mass concentration of each phase in the RQPA of the Yeelimitecontaining cements by Eq. (4):

$\mathrm{W}_{\alpha}=\mathrm{S}_{\alpha} \frac{\rho_{\alpha} \mathrm{V}_{\alpha}^{2} \mu_{\mathrm{s}}}{\mathrm{G}}$

Table 3

ICDD-PDF and ICSD collection codes for all phases used for Rietveld refinements.

\begin{tabular}{|c|c|c|c|c|c|c|c|}
\hline & PDF-code & ICSD code & Ref. & & PDF-code & ICSD code & Ref. \\
\hline $\mathrm{C}_{4} \mathrm{~A}_{3} \mathrm{~S}-\mathrm{O}$ & $01-085-2210$ & 80361 & [42] & M & 01-071-1176 & 9863 & {$[50]$} \\
\hline $\mathrm{C}_{4} \mathrm{~A}_{3} \overline{\mathrm{S}}-\mathrm{C}$ & 01-071-0969 & 9560 & [43] & $\mathrm{CA}$ & $01-070-0134$ & 260 & [51] \\
\hline$\gamma-C_{2} \bar{S}$ & 01-086-0397 & 81095 & [44] & $\mathrm{C}_{3} \mathrm{~S}$ & 01-070-8632 & 94742 & [52] \\
\hline $\mathrm{B}-\mathrm{C}_{2} \mathrm{~S}$ & 01-086-0398 & 81096 & [44] & $\mathrm{C}_{2} \mathrm{AS}$ & 01-089-5917 & 87144 & [53] \\
\hline$\alpha^{\prime}-C_{2} S$ & 01-086-0399 & 81097 & [44] & $\mathrm{C}_{5} \mathrm{~S}_{2} \mathrm{~S}$ & 01-070-1847 & 4332 & [54] \\
\hline$\alpha^{\prime}-C_{2} S$ (act.) & 01-086-0399 & - & [45] & Dolomite & 01-075-1711 & 31277 & [55] \\
\hline $\mathrm{C}_{4} \mathrm{AF}$ & 01-071-0667 & 9197 & [46] & Akermanite & $01-079-2425$ & 67691 & [56] \\
\hline $\mathrm{CT}$ & 01-078-1013 & 62149 & [47] & $\mathrm{Na}_{2} \mathrm{Si}_{2} \mathrm{O}_{5}$ & 01-089-8339 & 88662 & [57] \\
\hline CS & 01-072-0916 & 16382 & [48] & $\mathrm{Al}_{2} \mathrm{O}_{3}$ (standard) & $01-081-2267$ & 73725 & [58] \\
\hline $\mathrm{C} \overline{\mathrm{S}} \mathrm{H}_{2}$ & 00-033-0311 & 151692 & [49] & ZnO (standard) & 01-079-0206 & 65120 & [59] \\
\hline
\end{tabular}


Table 4

Computed G factor and selected structural details for the alumina standard used.

\begin{tabular}{|c|c|}
\hline Rietveld scale factor from GSAS program ${ }^{\mathrm{a}}$ & $236.60^{\mathrm{a}}$ \\
\hline $\mathrm{S}_{\mathrm{st}}\left(\mathrm{NIST} \mathrm{Al} \mathrm{O}_{3}\right)$ & 0.92748 \\
\hline Cell volume & $2.551 \cdot 10^{-22}\left(\mathrm{~cm}^{3}\right)$ \\
\hline Density & $3.998\left(\mathrm{~g} / \mathrm{cm}^{3}\right)$ \\
\hline MAC & $30.91\left(\mathrm{~cm}^{2} / \mathrm{g}\right)$ \\
\hline G-factor & $7.46 \cdot 10^{-42}\left(\mathrm{~cm}^{5} / \mathrm{wt} . \%\right)$ \\
\hline
\end{tabular}

a The individual phase scale factors provided in the GSAS program output are multiplied by each phase volume (in $\AA^{3}$ ). So, this has to be taken into account when using Eqs. (3) and (4).

This method allowed determining the absolute weight fractions by previously obtaining the diffractometer constant. However, the mass attenuation coefficients of the samples are needed, $\mu_{s}$. These values were independently determined by X-ray fluorescence

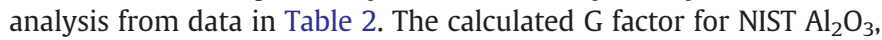
as well as selected structural details of the used standard, is given in Table 4. The mass attenuation coefficients (MAC) of the individual oxides (calculated with the HighScore Plus 2.2 program) were given in Table 2. Furthermore, the MAC values of the six studied samples were also given in that Table.

2.2.4.3. Internal standard method. An alternative method to quantify the ACn content is to use the internal standard method. In this approach, the sample is spiked with an appropriate standard that should fulfill at least three conditions. It must have an absorption coefficient close to the sample, negligible ACn content, and small average particle size in order to be easily homogenized with the sample under study. In our case, $\mathrm{ZnO}$ was used as internal standard. This compound was selected because its MAC value, $50.34 \mathrm{~cm}^{2} / \mathrm{g}$, yields a linear attenuation coefficient, $285 \mathrm{~cm}^{-1}$, very similar to those of the analyzed cements. Furthermore, its particle size is small, approximately $0.5 \mu \mathrm{m}$ as determined by scanning electron microscopy; its facecentered crystal structure gives a very simple pattern avoiding strong overlapping with the diffraction lines of the studied cements; and a previous study [60] showed very small, if any, ACn content.

A simple Rietveld refinement using the methodology explained in Section 2.2.4.1 will yield a set of weight fractions normalized to $100 \%$. However in this case, in addition to the weight fractions of the phases in the sample, the Rietveld refined weight fraction of the standard, $R_{s t}$, is also obtained. It should be kept in mind that the weight fraction added of the internal standard is precisely known, $\mathrm{W}_{\text {st. }}$. If the sample contains $A C n, R_{s t}$ will be (much) larger than $W_{s t}$. From this overestimation, the overall ACn content is derived according to Eq. (5) [32]:

$\mathrm{ACn}=\frac{1-\mathrm{W}_{\mathrm{st}} / \mathrm{R}_{\mathrm{st}}}{100-\mathrm{W}_{\mathrm{st}}} \times 10^{4} \%$

Once the overall ACn content of the sample under study, ACn, is known, the initial RQPA can be recalculated to yield the real sample phase contents. All details for these calculations have been already reported [32]. Furthermore, the errors associated to this approach and the optimum amount of standard has been recently discussed [61].

\section{Results and discussion}

\subsection{Standard RQPA of Yeelimite-containing clinkers/cement}

Three commercial CSA clinkers (ALIPRE®, BELITH_CS10 and S.A.cement), one CSA cement (CSA_trial) and two laboratory-prepared BCSA clinkers (BCSAF_B0 and BCSAF_B2) have been analyzed by LXRPD. Table 5 reports the direct RQPA results (wt.\%) obtained for these samples where Rietveld results were normalized to $100 \%$ of crystalline phases. These values were obtained from the approach described in Section 2.2.4.1, and hence, the presence of an ACn fraction is neglected. Standard deviations are derived from three independent measurements (not the mathematical errors from the Rietveld fits). These three analyses were carried out to different portions of the samples for better averaging (i.e. not recording three patterns for the same sample). Figs. 1 to 6 show a selected range of the Rietveld plots for the six studied Yeelimite-containing cements. The major peaks for each phase are labeled.

Several conclusions can be drawn from the phase analyses reported in Table 5.

I) Yeelimite, ideal stoichiometry $\mathrm{Ca}_{4} \mathrm{Al}_{6} \mathrm{O}_{12}\left(\mathrm{SO}_{4}\right)$, is known to crystallize in the tectosilicate sodalite type structure, $\mathrm{Na}_{4} \mathrm{Al}_{3} \mathrm{Si}_{3} \mathrm{O}_{12} \cdot \mathrm{Cl}$. Replacement of chloride by sulfate and partial replacement of sodium by calcium gives hauynite, $\mathrm{Na}_{3} \mathrm{CaAl}_{3} \mathrm{Si}_{3} \mathrm{O}_{12}\left(\mathrm{SO}_{4}\right)$. Both sodalite and hauynite minerals are cubic. However, some aluminates with sodalite structure are known to be orthorhombic, for instance $\mathrm{Ca}_{4} \mathrm{Al}_{6} \mathrm{O}_{12}\left(\mathrm{WO}_{4}\right)[62,63]$. Therefore, both orthorhombic and cubic structural descriptions have been included in the control file for the RQPA, see Table 3. It is noteworthy that five out of six studied samples contained a mixture of orthorhombic and cubic sodalite type-structures. Only, BCSAF_B2 sample showed just cubic Yeelimite. We speculate that this is due to the simultaneous presence of $\mathrm{Na}$, Fe and Si within cubic Yeelimite in BCSAF_B2. A deep synthetic and structural study of cubic and orthorhombic $\mathrm{C}_{4} \mathrm{~A}_{3} \mathrm{~S}$-type phases is in progress, including neutron powder diffraction, and it will be reported elsewhere.

II) It is also important to identify the belite polymorph and its quantification. Borax addition fully transforms $\beta$-belite in BCSAF_B0 to fully $\alpha^{\prime}{ }_{H}$-belite in BCSAF_B2, in complete agreement with a previous report [60]. The mechanism for the boraxactivation of belite has been very recently unravel as a solid

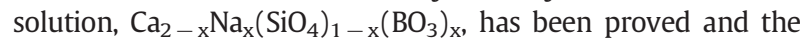
crystal structure of $\alpha^{\prime}{ }_{\mathrm{H}}-\mathrm{Ca}_{1.85} \mathrm{Na}_{0.15}\left(\mathrm{SiO}_{4}\right)_{0.85}\left(\mathrm{BO}_{3}\right)_{0.15}$ has been worked out [45]. It is also noteworthy that S.A.cement has a high $\alpha^{\prime}{ }^{\prime}$-belite content. This can be justified with the elemental

Table 5

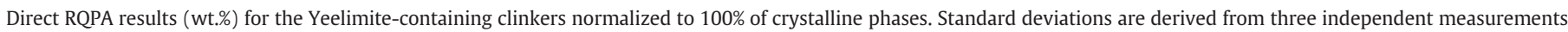
(not the mathematical errors from the Rietveld fit).

\begin{tabular}{|c|c|c|c|c|c|c|c|c|c|c|c|}
\hline & $\mathrm{C}_{4} \mathrm{~A}_{3} \mathrm{~S}-\mathrm{O}$ & $\mathrm{C}_{4} \mathrm{~A}_{3} \mathrm{~S}-\mathrm{C}$ & $\alpha^{\prime}-C_{2} S$ & $\beta-C_{2} S$ & $\mathrm{C}_{4} \mathrm{AF}$ & $\mathrm{CT}$ & M & $\mathrm{C}_{5} \mathrm{~S}_{2} \mathrm{~S}$ & $\mathrm{CSH}_{2}$ & $\mathrm{CS}$ & $\mathrm{C}_{3} \mathrm{~S}$ \\
\hline ALIPRE® ${ }^{\mathrm{a}}$ & $51.0(7)$ & $18.5(6)$ & $9.4(3)$ & $7.7(1)$ & & $3.5(1)$ & $0.52(2)$ & & & $9.0(4)$ & \\
\hline BELITH_CS10 & $40.1(9)$ & $25.5(6)$ & & $16.0(2)$ & $2.4(1)$ & $9.3(1)$ & $2.2(2)$ & & & & \\
\hline S.A.cement ${ }^{\mathrm{C}}$ & $27.5(5)$ & $28.7(6)$ & $21.4(9)$ & $9.7(4)$ & & $3.5(4)$ & $1.1(1)$ & & & $6.3(1)$ & \\
\hline CSA_trial $^{\mathrm{d}}$ & $16.5(1.3)$ & $23.6(7)$ & & $9.0(9)$ & & $4.8(2)$ & & $16.2(5)$ & $13.7(4)$ & $8.5(2)$ & $5.9(5)$ \\
\hline BCSAF_BO ${ }^{\mathrm{e}}$ & $14.6(1.1)$ & $13.5(1.2)$ & & $48.7(6)$ & $14.9(2)$ & $1.3(2)$ & & & & & \\
\hline BCSAF_B2 & & $31.1(1.7)$ & $56.7(1.8)$ & & $10.1(6)$ & $2.1(2)$ & & & & & \\
\hline
\end{tabular}

a Also contains $0.4(1)$ wt.\% Na2Si2O5

b Also contains 4.6(1) wt.\% of akermanite.

c Also contains 1.9(1) wt.\% of CA.

d Also contains 1.8(7) wt.\% of dolomite.

e Also contains 2.6(5) wt.\% of $\gamma-C_{2} S$ and 4.4(2) wt.\% of $C_{2} A S$. 


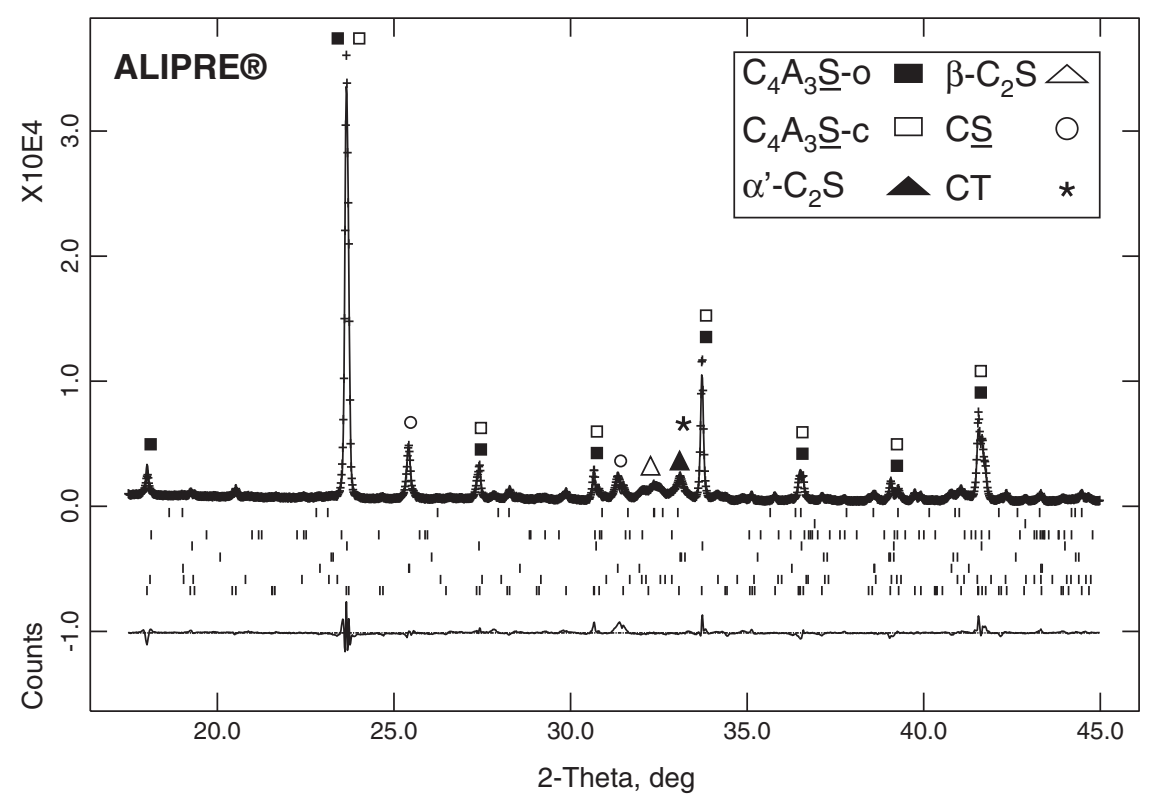

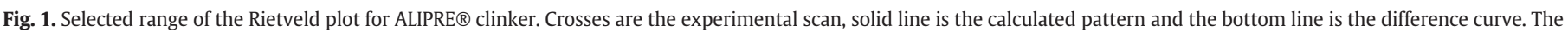
major peaks for each phase are labeled.

composition reported in Table 2 , as its $\mathrm{Na}_{2} \mathrm{O}$ content is quite high, 1.4 wt.\%. $\mathrm{Na}_{2} \mathrm{O}$ is known to stabilize $\alpha$-forms of belite $[64,65]$.

III) CS quantified in ALIPRE $®$, S.A.cement and CSA_trial is the high temperature polymorph, anhydrite-II [48]. So, this less reactive CS was likely produced during the clinkering process. It should be noted that gypsum, bassanite and less-soluble anhydrite-II can be easily distinguished and quantified by RQPA. However, bassanite and highly soluble anhydrite-III can only be distinguished in especial experimental conditions [66] with high-quality laboratory X-ray powder diffraction data.

IV) The good accuracy of the analyses can be estimated by the comparison of the XRF results (Table 2) and RQPA results (Table 5). RQPA showed the highest amount of periclase $(\mathrm{MgO})$ for BELITH_CS10, 2.2(2) wt.\%, and this is in full agreement with elemental analysis reported in Table 2, where this clinker showed the highest MgO content, 2.7 wt.\%. Furthermore,
S.A.cement was the second sample with the highest magnesium content determined by XRF, $1.5 \mathrm{wt} . \%$, and RQPA showed the second highest periclase content, $1.1 \mathrm{wt} . \%$. We choose to compare magnesium oxide contents because magnesium is little soluble in the Yeelimite structure.

$\mathrm{V})$ The presence of ternesite (also known as sulfate-spurrite), $\mathrm{C}_{5} \mathrm{~S}_{2} \mathrm{~S}$, is quite uncommon in CSA or BCSA clinkers. However, CSA_trial has a high amount of ternesite, 16.2(5) wt.\%. This is likely due to a very high $\mathrm{SO}_{3}$ dosage in the raw materials. XRF $\mathrm{SO}_{3}$ value for this cement, $16.7 \mathrm{wt} . \%$, is very high even taken into account the $\sim 14 \mathrm{wt} . \%$ of gypsum added. Overall $\mathrm{SO}_{3}$ values range approximately from 9 to $14 \mathrm{wt} . \%$ for CSA clinkers and between 3 and 4 wt.\% for BCSA clinkers.

VI) Titanium is usually present in CSA and BCSA cements as it accompanies aluminum in bauxites. High aluminum contents in CSA clinkers are linked to high titanium contents as shown

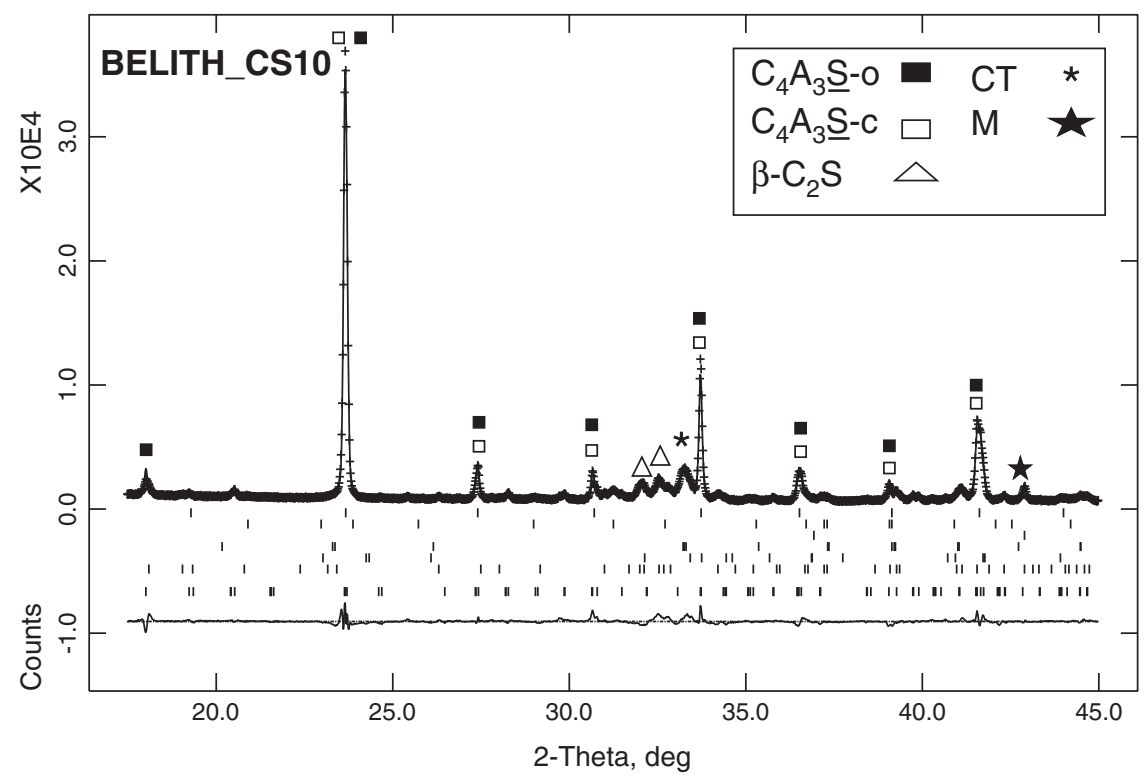

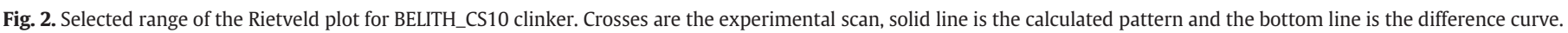
The major peaks for each phase are labeled. 


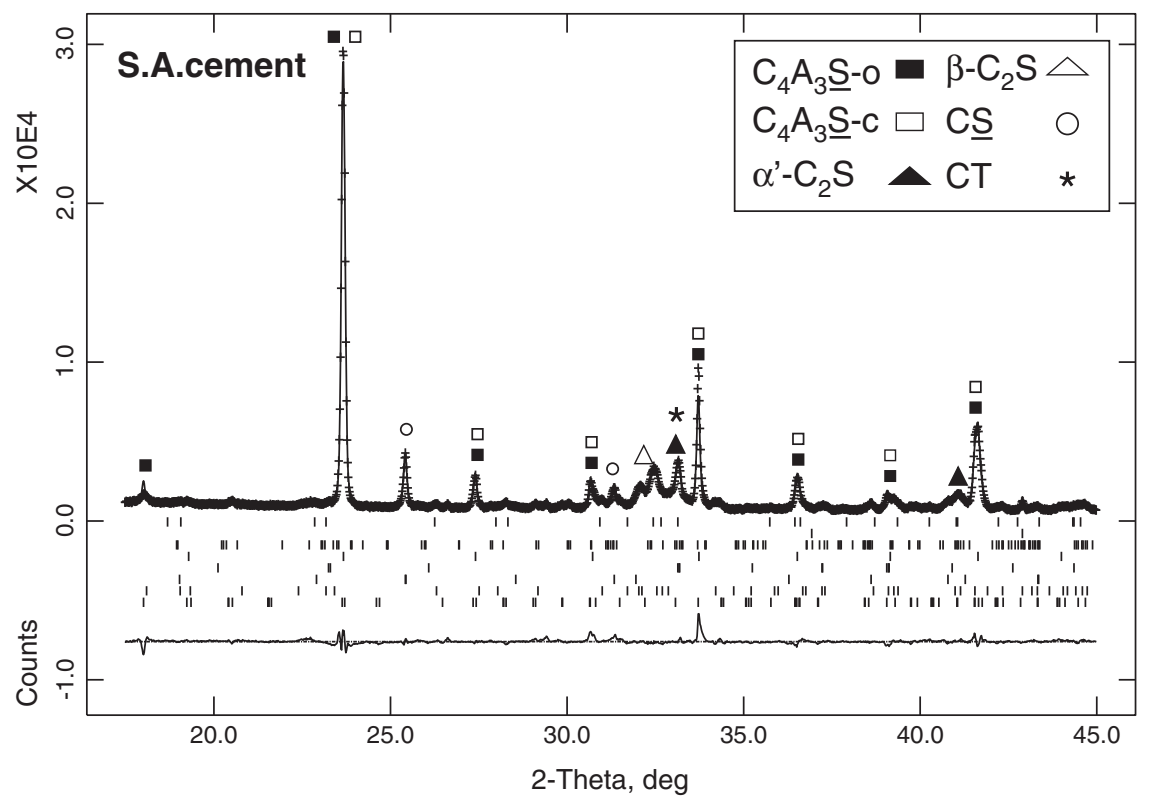

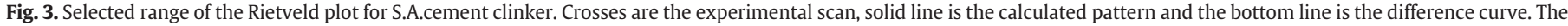
major peaks for each phase are labeled.

in Table 2. Consequently, lower aluminum contents in BCSA are linked to lower titanium contents. Furthermore, titanium may replace aluminum in some phases but the solubility limits are exceeded in CSA and BCSA clinkers. This is evident from the RQPA as the perovskite $\mathrm{CaTiO}_{3}$ phase segregates. We have carried out the RQPA with this assumed stoichiometry, $\mathrm{CaTiO}_{3}$, however further studies are needed in order to establish the stoichiometry of the perovskite phase as it is very well known that this phase forms extensive solid solutions with transition metals.

Finally, selective dissolutions have been carried out for BCSAF_B0 and BCSAF_B2, see Figs. 7 and 8. This work was carried out for a better characterization of these samples. For instance, it can be highlighted that the main peak of $\mathrm{CT}$ is strongly overlapped with the main peak of $\mathrm{C}_{3} \mathrm{~A}$ and merwinite, $\mathrm{Ca}_{3} \mathrm{Mg}\left(\mathrm{SiO}_{4}\right)_{2}$. Therefore, RQPA, itself, can not distinguish between these phases. Fig. 7 shows a small selected region of the Rietveld plots for BCSAF_B0 clinker plus the aluminate and silicate residues. Fig. 8 shows the same type of graphic for BCSAF_B2. The Rietveld plot for the silicate residue of BCSAF_BO is very informative as the diffraction peaks from $\mathrm{C}_{4} \mathrm{AF}$ disappear but the diffraction peak at $\sim 33.3^{\circ}(2 \theta)$ is still present. Hence, this phase could be perovskite or merwinite but not $\mathrm{C}_{3} \mathrm{~A}$. The Rietveld refinements of the silicate residue indicated that the fit with perovskite was better (lower R-factors) than that with merwinite.

Furthermore, a close analysis of the Rietveld plots of the residues indicates that the peak widths in the BCSAF_B2 are narrower than those in BCSAF_B0. For instance, the diffraction peaks from CT and

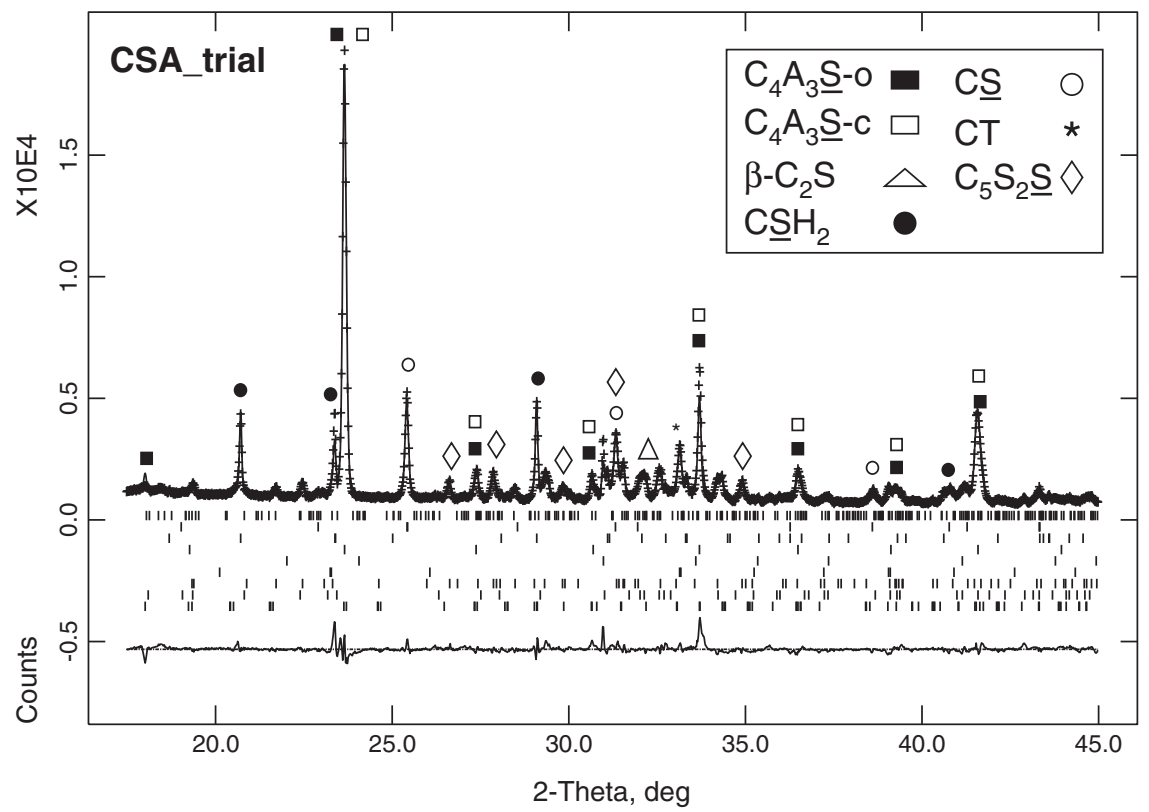

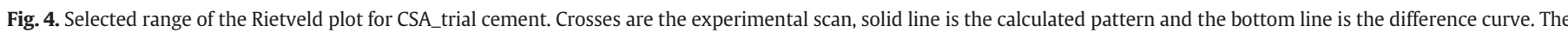
major peaks for each phase are labeled. 


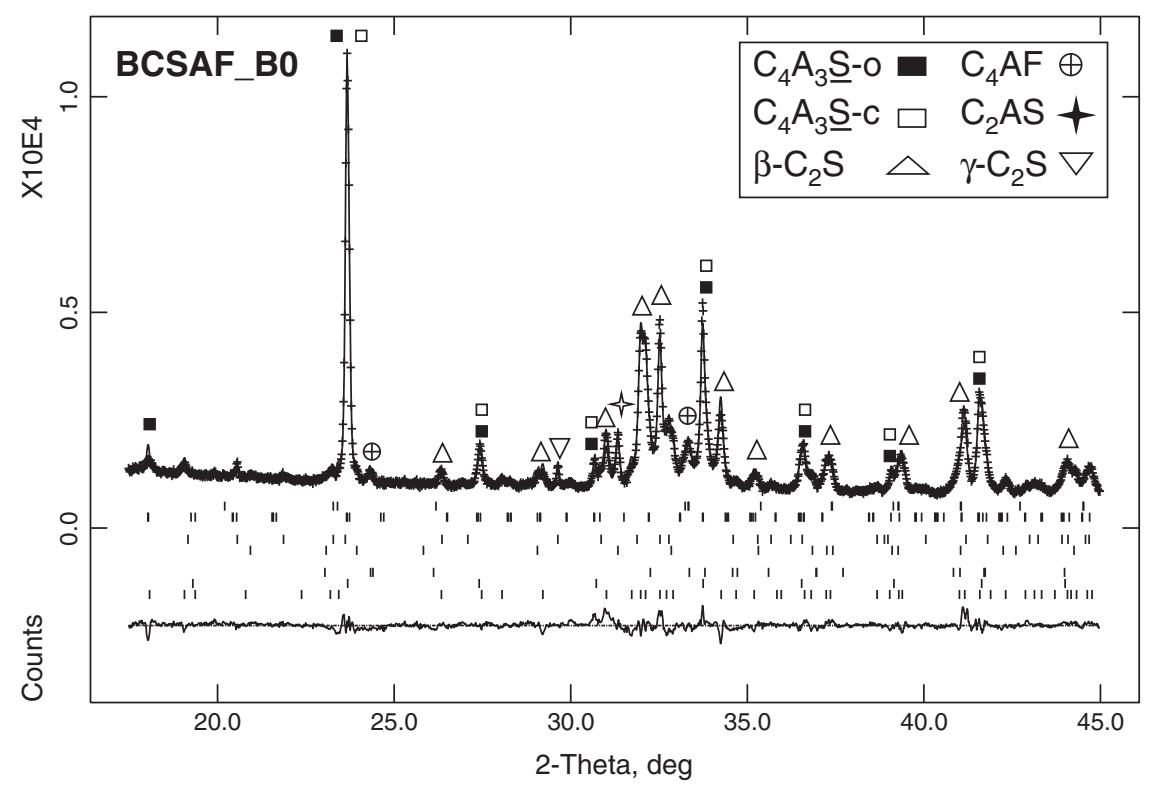

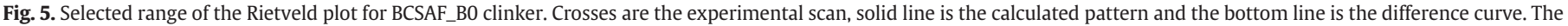
major peaks for each phase are labeled.

$\mathrm{C}_{4} \mathrm{~A}_{3} \mathrm{~S}$ in BCSAF_B2 aluminate fraction are narrower than those in the BCSAF_B0 aluminate fraction, see Figs. $8 \mathrm{~b}$ and $7 \mathrm{~b}$, respectively. This behavior is likely due to a better particle growth when borax is added. In fact, scanning electron microscopy data (not shown) indicate that the average particle sizes for BCSAF_B2 are larger than those of BCSAF_BO. However, the unit cell values of some phases change between the two studied clinkers. Furthermore, these values also slightly change between a clinker and the residues. So, the unit cell variations may also influence the degree of overlapping and consequently, some peak widths.

\subsection{Absolute RQPA of Yeelimite-containing clinkers/cement}

Table 6 shows the RPQA results (wt.\%) for the Yeelimite-containing samples including the ACn contents employing the two methodologies previously described. The values obtained from reflection geometry using an external standard (G-method) are given in the first row. The values obtained from transmission geometry using $\mathrm{ZnO}$ as internal standard are given in the second row. In both cases, standard deviations are derived from three independent measurements.

Three important conclusions can be drawn from the comparative study shown in Table 6. Firstly, using the G-factor (previously obtained with an external standard, see Table 4), it allowed measuring both the crystalline phases and the ACn contents. The ACn contents of CSA clinkers/cements are similar to those found in OPC cements, 10 wt.\% [30-32]. However, these contents are much higher in BCSA clinkers, of the order of $25 \mathrm{wt} . \%$. We would like to highlight that this measurement does not mean that there is about $25 \mathrm{wt}$.\% of amorphous/sub-cooled liquid in these clinkers. These high values are likely due to the high concentration of impurities and defects in belite.

Secondly, transmission powder diffraction data were also recorded for the same samples. An alternative methodology is always advisable

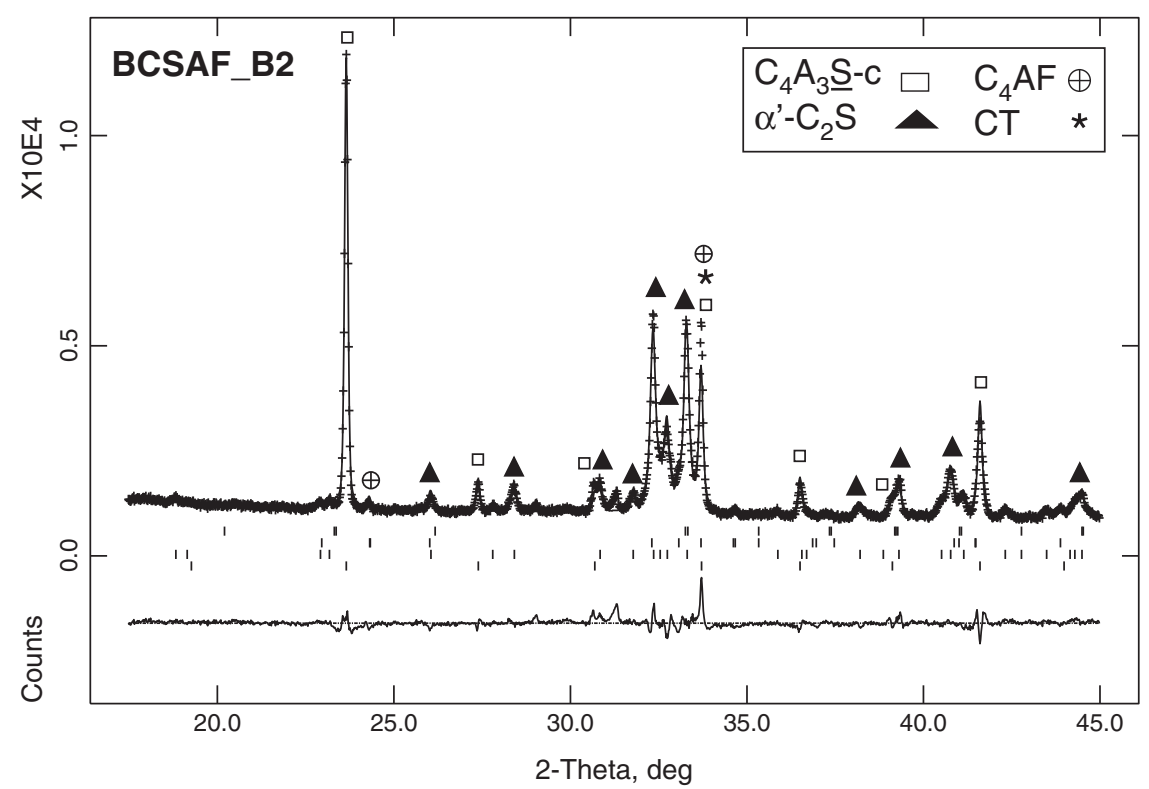

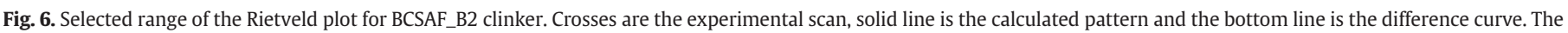
major peaks for each phase are labeled. 


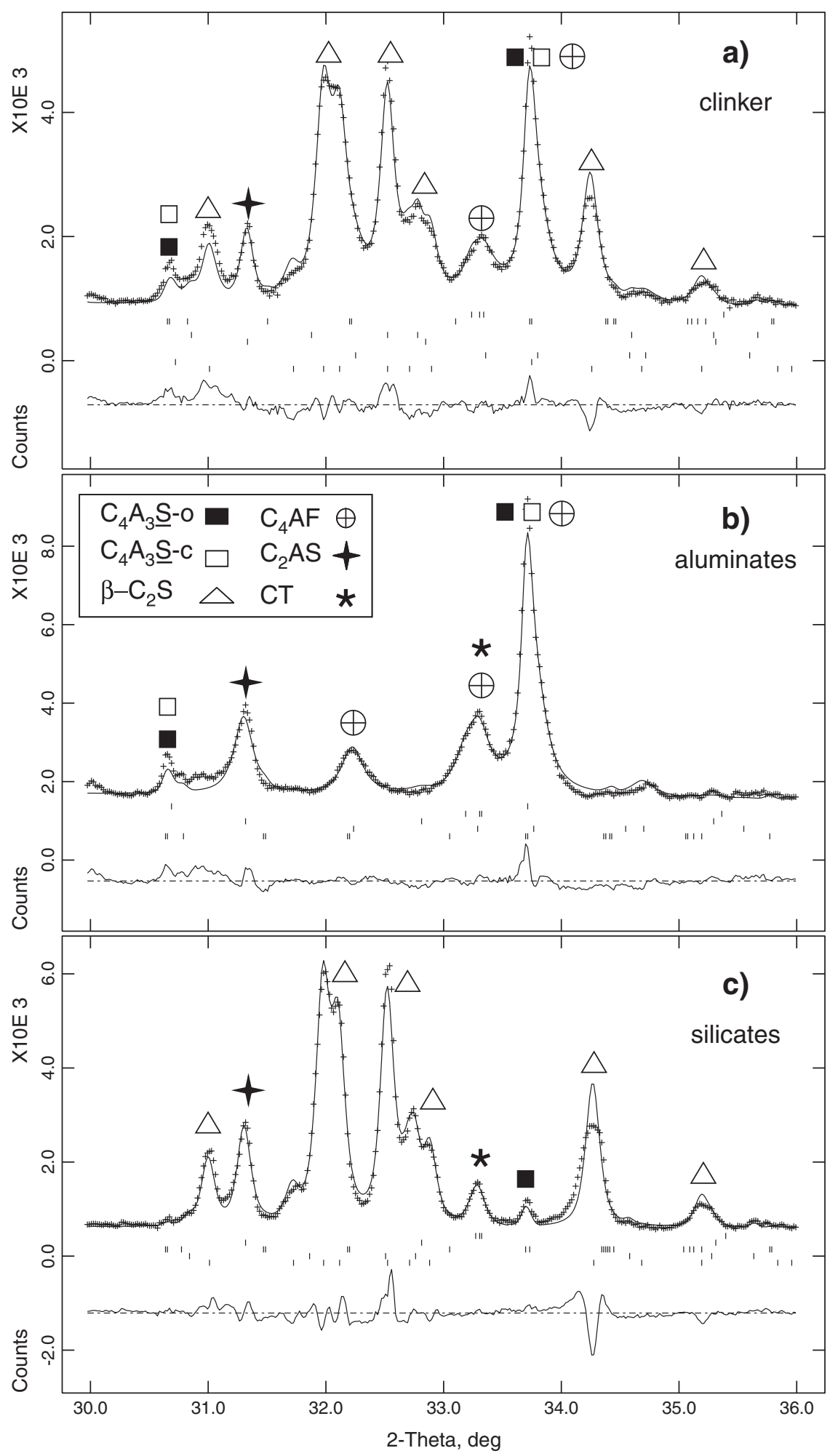

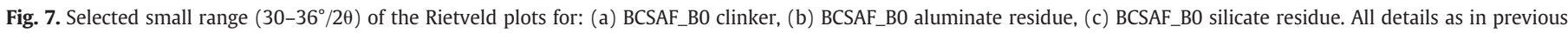
Rietveld figures.

to show the appropriateness of data recording and data analysis strategies. Furthermore, although the internal standard dilutes the phases in the samples, $\mathrm{ZnO}$ was added to determine the overall $\mathrm{ACn}$ contents. Table 6 also reports the analytical results obtained from this methodology. Overall, the same trend was obtained concerning the ACn contents. CSA clinkers have ACn contents close to $10 \mathrm{wt} . \%$ except for BELITH_CS10, which essentially had a cero value. Furthermore, the
BCSA clinkers displayed high ACn contents, 25 wt.\%, in full agreement with those obtained with the G-method.

For the internal standard method, the reported uncertainties in Table 6 are those arising from the average of three measurements. However, the uncertainties resulting from the amount of standard used, $25 \mathrm{wt} . \%$, are not taken into account. Therefore, the standard deviations reported for the ACn numbers are underestimated. Errors 


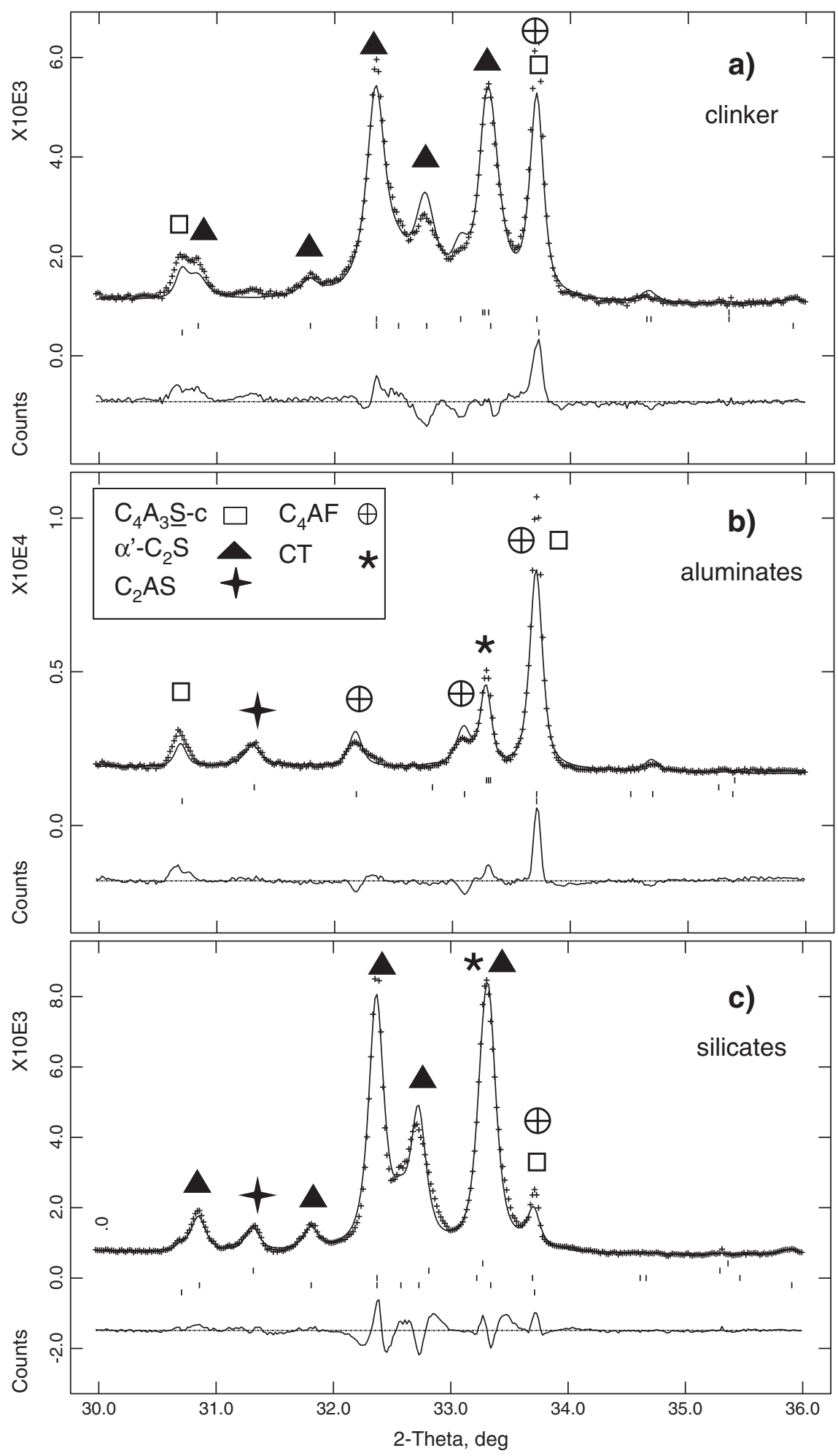

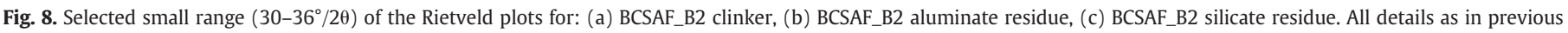
Rietveld figures.

close to 3 wt.\% are more likely to occur, but they are very difficult to quantify with precision.

Thirdly, a brief discussion on the results obtained by these two methods is worthy, see Table 6. For four samples, S.A.cement, CSA_trial, BCSA_B0 and BCSAF_B2, the Rietveld quantitative phase analysis values agree quite well. However, for ALIPRE® and BELITH_CS10, the results are not that satisfactory. For ALIPRE ${ }^{\circ}$, the differences in the quantification of $\mathrm{C}_{4} \mathrm{~A}_{3} \mathrm{~S}$-c, $\beta$-belite and $\mathrm{ACn}$ are $5.7,4.3$ and 10.3 wt.\%.
Three times the standard deviations is commonly used for a good level of confidence. So, the sum of $3 \sigma$ for the two analyses was calculated giving 3.0, 5.1 and 9.6 wt.\% for $C_{4} A_{3} S-c, \beta$-belite and $A C n$ values, respectively. Therefore, the quantification of $\mathrm{C}_{4} \mathrm{~A}_{3} \mathrm{~S}-\mathrm{c}$ for ALIPRE ${ }^{\circledR}$ is well out of the limits. For BELITH_CS10, the differences in the quantification of $\mathrm{C}_{4} \mathrm{~A}_{3} \mathrm{~S}-\mathrm{-}, \beta$-belite and $\mathrm{ACn}$ are $4.3,7.2$ and $14.5 \mathrm{wt} . \%$, with the sum of $3 \sigma$ for the two analyses giving 3.9, 3.9 and $5.7 \mathrm{wt} . \%$, respectively. In this case, the quantification of $\beta$-belite and $A C n$ does 
Table 6

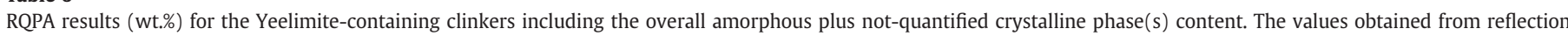

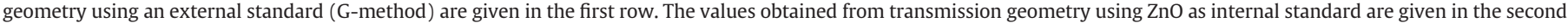
row (italics). Standard deviations are derived from three independent measurements (not the mathematical errors from the Rietveld fit).

\begin{tabular}{|c|c|c|c|c|c|c|c|c|c|c|c|c|}
\hline & $\mathrm{C}_{4} \mathrm{~A}_{3} \underline{\mathrm{S}}-\mathrm{O}$ & $\mathrm{C}_{4} \mathrm{~A}_{3} \mathrm{~S}-\mathrm{C}$ & $\alpha^{\prime}-C_{2} S$ & $\beta-C_{2} S$ & $\mathrm{C}_{4} \mathrm{AF}$ & $\mathrm{CT}$ & M & $\mathrm{C}_{5} \mathrm{~S}_{2} \mathrm{~S}$ & $\mathrm{CSH}_{2}$ & CS & $\mathrm{C}_{3} \mathrm{~S}$ & $\mathrm{ACn}^{\mathrm{a}}$ \\
\hline \multirow[t]{2}{*}{ ALIPRE $\circledR^{b}$} & $42.0(9)$ & $15.3(5)$ & $7.7(2)$ & $6.4(1)$ & & $2.9(1)$ & $0.43(1)$ & & & $7.5(4)$ & & $17.5(1.4)$ \\
\hline & $41.0(8)$ & $21.0(5)$ & $7.6(2)$ & $10.7(1.6)$ & & $3.0(2)$ & $0.5(2)$ & & & $8.2(1)$ & & 7.2(1.8) \\
\hline \multirow[t]{2}{*}{ BELITH_CS10 ${ }^{c}$} & $35.8(4)$ & $22.8(3)$ & & $14.3(3)$ & $2.1(1)$ & $8.3(2)$ & $2.0(2)$ & & & & & $10.6(8)$ \\
\hline & 40.1(9) & $23.0(9)$ & & $21.5(1.0)$ & $2.1(4)$ & $7.9(1)$ & 2.1(1) & & & & & $-3.9(1.1)$ \\
\hline \multirow[t]{2}{*}{ S.A.cement ${ }^{d}$} & $24.2(6)$ & 25.3(9) & $18.8(4)$ & $8.6(5)$ & & $3.1(4)$ & $0.92(2)$ & & & $5.6(2)$ & & $11.9(1.7)$ \\
\hline & $23.0(7)$ & $27.2(6)$ & 17.1(3) & $8.8(6)$ & & $2.9(1)$ & $0.7(1)$ & & & $6.1(1)$ & & $13.5(6)$ \\
\hline \multirow[t]{2}{*}{ CSA_trial ${ }^{\mathrm{e}}$} & $14.6(7)$ & $21.2(1.0)$ & & $8.0(1.1)$ & & $4.3(3)$ & & $14.4(8)$ & $12.2(7)$ & 7.6(1) & $5.3(6)$ & $10.8(2.9)$ \\
\hline & $14.3(6)$ & $20.7(8)$ & & $9.0(6)$ & & $3.4(2)$ & & $13.0(1)$ & $13.3(3)$ & $7.5(2)$ & $6.0(6)$ & $12.3(1.4)$ \\
\hline \multirow[t]{2}{*}{ BCSAF_BO ${ }^{\mathrm{f}}$} & $10.9(1.0)$ & $10.0(8)$ & & $36.2(1.3)$ & $11.1(2)$ & $1.0(1)$ & & & & & & $25.5(2.1)$ \\
\hline & $10.2(7)$ & $8.8(6)$ & & $33.3(1)$ & $12.9(3)$ & $0.6(2)$ & & & & & & $26.1(4)$ \\
\hline \multirow[t]{2}{*}{ BCSAF_B2 } & & $22.5(1.6)$ & $40.9(1.0)$ & & $7.3(4)$ & $1.5(2)$ & & & & & & $27.7(1.2)$ \\
\hline & & $22.1(3)$ & $41.9(4)$ & & $10.3(2)$ & $0.9(2)$ & & & & & & $24.9(9)$ \\
\hline
\end{tabular}

a ACn stands for amorphous plus not-quantified crystalline phase(s) which includes misfitting problems and not-computed phase(s).

b Also contains: $0.4(1)$ wt.\% $\mathrm{Na}_{2} \mathrm{Si}_{2} \mathrm{O}_{5} .0 .8(3)$ wt.\% $\mathrm{Na}_{2} \mathrm{Si}_{2} \mathrm{O}_{5}$.

c Also contains: 4.1(1) wt.\% akermanite. 7.3(1) wt.\% akermanite.

d Also contains 1.6(1) wt.\% CA. 0.8(2) wt.\% CA.

e Also contains 1.6(5) wt.\% dolomite. 1.0(4) wt.\% dolomite.

f Also contains 1.9(4) wt.\% $\gamma-C_{2} S$ and 3.3(2) wt.\% $C_{2}$ AS. 1.5(2) wt.\% $\gamma-C_{2} S$ and 6.7(3) wt.\% $C_{2} A S$.

not agree. We do not have a definitive answer for this behavior but correlations of the phase scale factors with the peak shape parameters may be likely playing a role.

Finally, it is worth to highlight the importance of having accurate structural description for every phase in the cements to be analyzed. This is more important for high-content phases, and it will be illustrated for the RQPA of BCSAF_B2. If the 'old' approximate crystal structure of $\alpha^{\prime}{ }_{\mathrm{H}^{-}} \mathrm{C}_{2} \mathrm{~S}$ is used [44], one Rietveld fit of the reflection data gave $R_{W P}=5.22 \%$ and $R_{F}\left(\alpha^{\prime}{ }^{-} C_{2} S\right)=7.24 \%$. The application of the G-method gave $\alpha^{\prime}{ }_{H}-C_{2} S$ and $A C n$ contents of 35 and $33 w t . \%$, respectively. If a better structural description is used, $\alpha^{\prime}{ }_{H^{-}} \mathrm{Ca}_{1.85}$ $\mathrm{Na}_{0.15}\left(\mathrm{SiO}_{4}\right)_{0.85}\left(\mathrm{BO}_{3}\right)_{0.15}$ [45], then, the Rietveld fit of the same pattern was better (lower disagreement factors): $\mathrm{R}_{\mathrm{WP}}=4.87 \%$ and $\mathrm{R}_{\mathrm{F}}\left(\alpha^{\prime}{ }_{\mathrm{H}^{-}} \mathrm{C}_{2} \mathrm{~S}\right)=5.72 \%$. This better fit gave a larger $\alpha^{\prime}{ }_{\mathrm{H}^{-}} \mathrm{C}_{2} \mathrm{~S}$ scale factor (30.94 instead of 25.53) and therefore, the $\alpha^{\prime}{ }_{\mathrm{H}}{ }^{-} \mathrm{C}_{2} \mathrm{~S}$ content was larger (40 wt.\%) and ACn content smaller, 28 wt.\%. So, the use of approximate crystal structures gives lower determined crystalline phase contents and higher ACn contents, as expected.

\section{Conclusions}

Rietveld quantitative phase analyses of three commerciallyavailable calcium sulfoaluminate clinkers have been successfully carried out. In addition, two laboratory prepared iron-rich belite calcium sulfoaluminate clinkers have been also studied. All commercial CSA clinkers contained mixtures of orthorhombic and cubic Yeelimites. Only, the borax-activated BCSA clinker contained just cubic-Yeelimite. Moreover borax addition transforms $\beta$-belite in BCSAF_B0 to fully $\alpha^{\prime}{ }^{\prime}$-belite in BCSAF_B2. Other accompanying phases have been quantified. It has been found a good agreement between elemental compositions obtained by X-ray fluorescence and mineralogical compositions obtained by Rietveld analysis of powder diffraction data as shown for $\mathrm{MgO} /$ periclase. Selective dissolutions were employed to better characterize the iron-rich belite calcium sulfoaluminate clinkers. Using this approach, every phase in the samples was firmly established. Finally, the ACn contents of these materials were measured by both external and internal standard methods. The agreement was fairly good for some cements but the variations for ALIPRE® and BELITH_CS10 were larger than expected. Overall, the analyses showed that the commercial calcium sulfoaluminate clinkers have ACn contents quite similar to those of OPCs, $\sim 10 \mathrm{wt} . \%$. Conversely, the ACn contents of the belite calcium sulfoaluminate clinkers were higher, $25 \mathrm{wt} . \%$.

\section{Acknowledgments}

This work has been supported by Spanish Ministry of Science and Innovation through MAT2010-16213 research grant, which is cofunded by FEDER. I.S. thanks a Ramón y Cajal fellowship, RYC-200803523.

\section{References}

[1] A. Klein, Calciumaluminosulfate and expansive cements containing same, US Patent No. 3, 155, 526 (1963) 4 pp.

[2] Y. Wang, M. Su, The third cement series in China, World Cem. 25 (1994) 6-10.

[3] E.M. Gartner, Industrially interesting approaches to "low- $\mathrm{CO}_{2}$ " cements, Cem. Concr. Res. 34 (2004) 1489-1498.

[4] G.S. Li, G. Walenta, E.M. Gartner, Formation and hydration of low- $\mathrm{CO}_{2}$ cements based on belite, calcium sulfoaluminate and calcium aluminoferrite, Proceedings of the 12th ICCC, Montreal, Canada, 2007, TH3-15.3.

[5] M.C.G. Juenger, F. Winnefeld, J.L. Provis, J.H. Ideker, Advances in alternative cementitious binders, Cem. Concr. Res. 41 (2011) 1232-1243.

[6] Q. Zhou, N.B. Milestone, M. Hayes, An alternative to Portland cement for waste encapsulation-the calcium sulfoaluminate cement system, J. Hazard. Mater. 136 (2006) 120-129.

[7] F.P. Glasser, L. Zhang, High-performance cement matrices based on calcium sulphoaluminate-belite compositions, Cem. Concr. Res. 31 (2001) 1881-1886.

[8] J. Beretka, M. Marroccoli, N. Sherman, G.L. Valenti, The influence of $C_{4} A_{3} S$ content and WS ratio on the performance of calcium sulfoaluminate-based cements, Cem. Concr. Res. 26 (1996) 1673-1681.

[9] S. Sahu, J. Majling, Preparation of sulphoaluminate belite cement from fly ash, Cem. Concr. Res. 24 (1994) 1065-1072.

[10] I. Odler, Special Inorganic Cements, Taylor and Francis Publisher, 2000, pp. 69-74, Cap. 4.

[11] F. Winnefeld, S. Barlag, Calorimetric and thermogravimetric study on the influence of calcium sulfate on the hydration of yeelimite, J. Therm. Anal Calorim. 101 (2010) 949-957.

[12] S. Berger, C.C.D. Coumes, P. Le Bescop, D. Damidot, Influence of a thermal cycle at early age on the hydration of calcium sulphoaluminate cements with variable gypsum contents, Cem. Concr. Res. 41 (2011) 149-160.

[13] I.A. Chen, C.W. Hargis, M.C.G. Juenger, Understanding expansion in calcium sulfoaluminate-belite cements, Cem. Concr. Res. 42 (2012) 51-60.

[14] L. Zhang, F.P. Glasser, Hydration of calcium sulfoaluminate cement at less than 24 h, Adv. Cem. Res. 14 (2002) 141-155.

[15] G.S. Li, E.M. Gartner, High-belite sulfoaluminate clinker: fabrication process and binder preparation, World Patent Application WO 2006/018569 A2.

[16] K. Quillin, Performance of belite-sulfoaluminate cements, Cem. Concr. Res. 31 (2001) 1341-1349.

[17] I. Janotka, U. Krajci, S.C. Mojumdar, Performance of sulphoaluminate-belite cement with high $\mathrm{C}_{4} \mathrm{~A}_{3} \$$ content, Ceram. Silik. 51 (2007) 74-81.

[18] D. Adolfsson, N. Menad, E. Viggh, B. Bjorkman, Hydraulic properties of sulphoaluminate belite cement based on steelmaking slags, Adv. Cem. Res. 19 (2007) 133-138.

[19] J. Pera, J. Ambroise, New applications of calcium sulfoaluminate cement, Cem. Concr. Res. 34 (2004) 671-676.

[20] G. Walenta, C. Comparet, V. Morin, E. Gartner, Hydraulic binder based on sulfoaluminate clinker and minerals additions, World Patent Application WO 2010/070215 A1 (2010) 
[21] G. Walenta, E. Gartner, V. Morin, Additives for hydraulic binder based on iron-rich belite calcium sulfoaluminate clinker, World Patent Application WO 2011/020958 A1 (2011).

[22] A. Wolter, Belite cements and low energy clinker, Cem. Inter. 3 (2005) 106-117.

[23] G.L. Valenti, M. Marroccoli, F. Montagnaro, M. Nobili, A. Telesca, Synthesis, hydration properties and environmental friendly features of calcium sulfoaluminate cements, Proceedings of the 12th International Congress of Cement Chemistry, Montreal, 2007, W3 11.2.

[24] M.C. Martín-Sedeño, A.J.M. Cuberos, A.G. De la Torre, G. Álvarez-Pinazo, L.M. Ordónez, M. Gateshki, M.A.G. Aranda, Aluminum-rich belite sulfoaluminate cements: clinkering and early age hydration, Cem. Concr. Res. 40 (2010) 359-369.

[25] A.G. De la Torre, A.J.M. Cuberos, G. Alvarez-Pinazo, A. Cuesta, M.A.G. Aranda, In situ powder diffraction study of belite sulfoaluminate clinkering, J. Synchrotron Radiat. 18 (2011) 506-514.

[26] J. Li, H. Ma, H. Zhao, Preparation of sulphoaluminate-alite composite mineralogical phase cement clinker from high alumina fly ash, Key Eng. Mater. 334-335 (2007) 421-424.

[27] H.M. Rietveld, A profile refinement method for nuclear and magnetic structures, J. Appl. Crystallogr. 2 (1969) 65-71.

[28] D.L. Bish, S.A. Howard, Quantitative phase analysis using the Rietveld method, J. Appl. Crystallogr. 21 (1988) 86-91.

[29] O. Pritula, L. Smrcok, B. Baumgartner, On reproducibility of Rietveld analysis of reference Portland cement clinkers, Powder Diffr. 18 (2003) 16-22.

[30] P.M. Suherman, A.V. Riessen, B. O'connor, D. Li, D. Bolton, H. Fairhurst, Determination of amorphous phase levels in Portland cement clinker, Powder Diffr. 17 (2002) 178-185.

[31] P.S. Whitfield, L.D. Mitchell, Quantitative Rietveld analysis of the amorphous content in cements and clinkers, J. Mater. Sci. 38 (2003) 4415-4421.

[32] A.G. De la Torre, S. Bruque, M.A.G. Aranda, Rietveld quantitative amorphous content analysis, J. Appl. Crystallogr. 34 (2001) 196-202.

[33] J.P. Cline, R.B. Von Dree, R. Winburn, P.W. Stephens, J.J. Filliben, Addressing the amorphous content issue in quantitative phase analysis: the certification of NIST standard reference material 676a, Acta Crystallogr., Sect. A: Found. Crystallogr. 67 (2011) 357-367.

[34] B.H. O'Connor, M.D. Raven, Application of the Rietveld refinement procedure in assaying powdered mixtures, Powder Diffr. 3 (1988) 2-6.

[35] D. Jansen, Ch. Stabler, F. Goetz-Neunhoeffer, S. Dittrich, J. Neubauer, Does Ordinary Portland Cement contain amorphous phase? A quantitative study using an external standard method, Powder Diffr. 26 (2011) 31-38.

[36] D. Jansen, F. Goetz-Neunhoeffer, B. Lothenbach, J. Neubauer, The early hydration of Ordinary Portland Cement (OPC): an approach comparing measured heat flow with calculated heat flow from QXRD, Cem. Concr. Res. 42 (2012) 134-138.

[37] J. Wang, Hydration mechanism of cements based on low- $\mathrm{CO}_{2}$ clinkers containing belite, ye'elimite and calcium alumino-ferrite, PhD Thesis, University of Lille (2010).

[38] A.C. Larson, R.B. Von Dreele, General Structure Analysis System (GSAS), Los Alamos National Laboratory Report LAUR, 2000, pp. 86-748.

[39] P. Thompson, D.E. Cox, J.B. Hasting, Rietveld refinement of Debye-Scherrer synchrotron X-ray data from $\mathrm{Al}_{2} \mathrm{O}_{3}$, J. Appl. Crystallogr. 20 (1987) 79-83.

[40] L.W. Finger, D.E. Cox, A.P. Jephcoat, A correction for powder diffraction peak asymmetry due to diaxial divergence, J. Appl. Crystallogr. 27 (1994) 892-900.

[41] W.A. Dollase, Correction of intensities for preferred orientation in powder diffractometry: application of the March model, J. Appl. Crystallogr. 19 (1986) 267-272.

[42] N.J. Calos, C.H.L. Kennard, A.K. Whittaker, R.L. Davis, Structure of calcium aluminate sulphate $\mathrm{Ca}_{4} \mathrm{Al}_{6} \mathrm{O}_{16} \mathrm{~S}$, J. Solid State Chem. 119 (1995) 1-7.

[43] H. Saalfeld, W. Depmeier, Silicon-free compounds with sodalite structure, Krist. Tech. 7 (1972) 229-233.
[44] W.G. Mumme, R.J. Hill, G. Bushnell-Wye, E.R. Segnit, Rietveld crystal structure refinement, chemistry and calculated powder diffraction data for the polymorphs of dicalcium silicate and related phases, N. Jb. Miner. Abh. 169 (1995) 35-68.

[45] A. Cuesta, E.R. Losilla, M.A.G. Aranda, A.G. De la Torre, Reactive belite stabilization mechanisms by boron-bearing dopants, Cem. Concr. Res. 42 (2012) 598-606.

[46] A.A. Colville, S. Géller, The crystal structure of brownmillerite, $\mathrm{Ca}_{2} \mathrm{FeAlO}_{5}$, Acta Crystallogr. B27 (1971) 2311-2315.

[47] S. Sasaki, C.T. Prewitt, J.D. Bass, Orthorhombic perovskite $\mathrm{CaTiO}_{3}$ and $\mathrm{CdTiO}_{3}$ : structure and space group, Acta Crystallogr. C43 (1987) 1668-1674.

[48] A. Kirfel, G. Will, Charge density in anhydrite, $\mathrm{CaSO}_{4}$, from X-ray and neutron diffraction, Acta Crystallogr. B36 (1980) 2881-2890.

[49] A.G. De la Torre, M.G. Lopez-Olmo, C. Alvarez-Rua, S. Garcia-Granda, M.A.G. Aranda, Structure and microstructure of gypsum and its relevance to Rietveld quantitative phase analyses, Powder Diffr. 19 (2004) 240-246.

[50] S. Sasaki, K. Fujino, Y. Takeuchi, X-ray determination of electron-density distributions in oxides, $\mathrm{MgO}, \mathrm{MnO}, \mathrm{CoO}$, and $\mathrm{NiO}$, and atomic scattering factors of their constituent atoms, Proc. Jpn Acad. 55 (1979) 43-48.

[51] W. Hörkner, Hk. Müller-Buschbaum, Crystal-structure of $\mathrm{CaAl}_{2} \mathrm{O}_{4}$, Inorg. Nuclear Chem. 38 (1976) 983-984.

[52] A.G. De la Torre, S. Bruque, J. Campo, M.A.G. Aranda, The superstructure of $C_{3} S$ from synchrotron and neutron powder diffraction and its role in quantitative phase analyses, Cem. Concr. Res. 32 (2002) 1347-1356.

[53] S.J. Louisnathan, Refinement of the crystal structure of a natural gehlenite, Ca2Al(Al, Si)O7, Can. Min. 10 (1971) 822-837.

[54] P.D. Brotherton, J.M. Epstein, M.W. Pryce, A.H. White, Crystal structure of calcium sulphosilicate, $\mathrm{Ca}_{5}\left(\mathrm{SiO}_{4}\right)_{2}\left(\mathrm{SO}_{4}\right)$, Aust. J. Chem. 27 (1974) 657-660.

[55] H. Effenberger, A. Kirfel, G. Wil, Studies of the electron-density distribution of dolomite, $\mathrm{CaMg}\left(\mathrm{CO}_{3}\right)_{2}$, Tschermaks Mineralog. Petrogr. Mitt. 31 (1983) 151-164.

[56] I.P. Swainson, M.T. Dove, W.W. Schmahl, A. Putnis, Neutron diffraction study of the akermanite-gehlenite solid solution series, Phys. Chem. Miner. 19 (1992) 185-195.

[57] V. Kahlenberg, G. Doersam, M. Wendschuh-Josties, R.X. Fischer, The crystal structure of delta-( $\left.\mathrm{Na}_{2} \mathrm{Si}_{2} \mathrm{O}_{5}\right)$, J. Solid State Chem. 146 (1999) 380-386.

[58] E.N. Maslen, V.A. Streltsov, N.R. Streltsova, N. Ishizawa, Y. Satow, Synchrotron Xray study of the electron density in alpha- $\mathrm{Al}_{2} \mathrm{O}_{3}$, Acta Crystallogr. B49 (1993) 973-980.

[59] J. Albertsson, S.C. Abrahams, A. Kvick, Atomic displacement, anharmonic thermal vibration, expansivity and pyroelectric coefficient thermal dependences in $\mathrm{ZnO}$, Acta Crystallogr. B45 (1989) 34-40.

[60] A.J.M. Cuberos, A.G. De la Torre, G. Álvarez-Pinazo, M.C. Martín-Sedeño, K. Schollbach, H. Pöllmann, M.A.G. Aranda, Active iron-rich belite sulfoaluminate cements: clinkering and hydration, Environ. Sci. Technol. 44 (2010) 6855-6862.

[61] T. Westphal, T. Füllmann, H. Pöllmann, Rietveld quantification of amorphous portions with an internal standard-mathematical consequences of the experimental approach, Powder Diffr. 24 (2009) 239-243.

[62] W. Depmeier, Aluminate sodalite $\mathrm{Ca}_{8}\left[\mathrm{Al}_{12} \mathrm{O}_{24}\right]\left(\mathrm{WO}_{4}\right)_{2}$ at room temperature, Acta Crystallogr. C40 (1984) 226-231.

[63] W. Depmeier, Structure of cubic aluminate sodalite $\mathrm{Ca}_{8}\left[\mathrm{Al}_{12} \mathrm{O}_{24}\right]\left(\mathrm{WO}_{4}\right)_{2}$ in comparison with its orthorhombic phase and with cubic $\mathrm{Sr}_{8}\left[\mathrm{Al}_{12} \mathrm{O}_{24}\right]\left(\mathrm{CrO}_{4}\right)_{2}$, Acta Crystallogr. B44 (1988) 201-207.

[64] K. Morsli, A.G. De la Torre, S. Stober, A.J.M. Cuberos, M. Zahir, M.A.G. Aranda, Quantitative phase analysis of laboratory-active belite clinkers by synchrotron powder diffraction, J. Am. Ceram. Soc. 90 (2007) 3205-3212.

[65] K. Morsli, A.G. De la Torre, M. Zahir, M.A.G. Aranda, Mineralogical phase analysis of alkali and sulfate bearing belite rich laboratory clinkers, Cem. Concr. Res. 37 (2007) 639-646.

[66] S. Seufert, C. Hesse, F. Goetz-Neunhoeffer, J Neubauer, Discrimination of bassanite and anhydrite III dehydrated from gypsum at different temperatures, Z. Kristallogr. Suppl. 30 (2009) 447-452. 